\title{
Early Modern Attitudes toward the Delegation of Copying and Note-Taking
}

\section{Citation}

Blair, Ann. 2016. "Early Modern Attitudes toward the Delegation of Copying and Note-Taking." In Forgetting Machines: Knowledge Management Evolution in Early Modern Europe, ed. Alberto Cevolini, 265-85. Leiden: Brill.

\section{Published Version}

doi:10.1163/9789004325258_013

\section{Permanent link}

http://nrs.harvard.edu/urn-3:HUL.InstRepos:33980566

\section{Terms of Use}

This article was downloaded from Harvard University's DASH repository, and is made available under the terms and conditions applicable to Open Access Policy Articles, as set forth at http:// nrs.harvard.edu/urn-3:HUL.InstRepos:dash.current.terms-of-use\#OAP

\section{Share Your Story}

The Harvard community has made this article openly available.

Please share how this access benefits you. Submit a story.

Accessibility 
Ann Blair, Dept of History, Harvard University

\section{Early modern attitudes toward the delegation of copying and note-taking ${ }^{1}$}

Autograph writing was valued in a number of ways in the early modern period: by writers as a mental and physical discipline that sharpened attention and retention, by readers as a privileged point of access to the person writing, and by both as a warrant of authenticity or a sign of affection or of special personal attention. At the same time handwriting was also often considered a chore best delegated to helpers--including secretaries in long-term employ, scriveners hired for a particular task, other servants, family members, friends, or students. In practice some scholars did a lot of writing themselves, while others dictated and delegated copying or note-taking, whether because of ill health, failing eyesight, poor handwriting, or a desire to get more work done faster. ${ }^{2}$ Generally I have found only a few explicit discussions of the decisions concerning delegating writing--in advice about working methods, or brief allusions to special circumstances in printed prefaces or in letters-- while a vast expanse of surviving manuscripts bears witness to practices not always in line with the attitudes articulated explicitly. From these two kinds of sources (for the latter of which I often rely on existing case studies and editorial notes), I'd like to ask both what early modern scholars delegated and what they admitted to delegating. From these questions I hope we can learn more about working methods, about the value associated with handwriting after the introduction of printing, and about the role of "invisible helpers" who were likely much more present in early modern scholarship than is apparent from the printed record. ${ }^{3}$

Most portraits we have of early modern scholars at work depict a man alone in his study with books and instruments of writing. But humanists worked with others of varying social and intellectual status. They shared information and sources with peers in person (in social gatherings seen as proto-academies) and in their correspondence, and often acknowledged these interactions in which rivalry was intermixed with collaboration, e.g. by citing, criticizing, praising, or thanking their interlocutors in print. Humanists portrayed themselves as participants in a Republic of Letters that extended across time and space, comprising social and intellectual peers engaged in a collective scholarly endeavor. These forms of collaboration invite comparisons with other contexts of collaborative work in this period, including play-writing in England, novel-writing in the

\footnotetext{
${ }^{1}$ I am grateful to Lauren Kassell and Elaine Leong for the conference they organized on "Notebooks, Medicine and the Sciences in Early Modern Europe" in July 2013 and to all the participants there for valuable feedback, especially Richard Yeo. Warm thanks to Alberto Cevolini for his invitation to contribute to this volume.

${ }^{2}$ A further motivation less relevant to scholars was embarrassment about poor writing skills.

${ }^{3}$ I borrow the term from the inspiring piece by Stephen Shapin, "The Invisible Technician," The American Scientist 77 (1989), pp. 554-63.
} 
French salons, and collaborative work in more or less formalized academies, from the Accademia dei Lyncei to the Royal Society. ${ }^{4}$

Other humanists are the most visible, but were not the only kinds of people with whom scholars worked. A spate of recent work on the early modern France has emphasized the interactions of authors with their printers for example. ${ }^{5}$ But the production of manuscripts through reading, note-taking, writing, and copying also often involved helpers, typically social or intellectual inferiors (e.g. due to age or gender), ranging from copyists to trusted amanuenses, paid in wages or in kind, or who contributed more or less voluntarily as students or as family members who stood to gain in personal experience and/or from the success of their professor or relative. Focusing on late humanist scholarship presents the distinct advantage that the working papers of scholars survive in greater numbers than they do for literary figures from the same period. ${ }^{6}$

\section{THE NEW STATUS OF HANDWRITING IN THE EARLY MODERN PERIOD} A larger historical perspective suggests that decisions about delegating writing became more complex in the early modern period, when writing in one's own hand was no longer exceptional and relying on the hand of another to write was not yet unusual--there were two real options to choose from. The norm in antiquity and much of the middle ages was to compose by dictation, so that authorial composition was a mental process rather than a

\footnotetext{
${ }^{4}$ As an entry into the world of English play-writing see Brian Vickers, Shakespeare, coauthor. A historical study of five collaborative plays (Oxford: Oxford University Press, 2003); on French novel-writing in the salons, see Joan DeJean, Tender Geographies : women and the origins of the novels in France (New York: Columbia University Press, 1991). On specific examples of collaborative work in the early modern period see: Adam Nicolson, God's Secretaries: the Making of the King James Bible (New York: HarperCollins, 2003); Anthony Grafton, "Where was Salomon's House? Eccelesiastical History and the Intellectual Origins of Bacon's New Atlantis," in Die Europäische Gelehrtenrepublik im Zeitalter des Konfessionalismus, Wolfenbütteler Forschungen_96 (2001): 21-39; reprinted in Worlds Made by Words: Scholarship and Community in the Modern West (Cambridge, MA: Harvard University Press, 2009), ch. 5. John Considine, Academy dictionaries 1600-1800 (Cambridge: Cambridge University Press, 2014).

${ }^{5}$ See Martine Furno (ed.), Qui écrit? Figures de l'auteur et des co- élaborateurs du texte XVe-XVIIIe siècle (Lyon, ENS Éditions/Insitut d'Histoire du Livre, 2009); Edwige Keller-Rahbé (ed.), Les arrière-boutiques de la littérature: auteurs et imprimeurslibraires aux XVIe et XVIIe siècles (Toulouse: Presses Universitaires du Mirail, 2010); Raphaële Mouren (ed.), Quid Novi? Sébastien Gryphe à l'occasion du 450e anniversaire de sa mort (Villeurbanne: Presses de l'ENSSIB, 2008); Brigitte Ouvry-Vial and Anne Réach-Ngô (eds.), L'acte éditorial: publier à la Renaissance et aujourd'hui_(Paris : Classiques Garnier, 2010); Alain Riffaud (ed.), L'écrivain et l'imprimeur (Rennes: Presses Universitaires de Rennes, 2010).

${ }^{6}$ See Michel Espagne, De l'archive au texte: recherches d'histoire génétique (Paris : Presses universitaires de France, 1998), 217; and most recently Roger Chartier, "The Author's Hand," in The Author's Hand and the Printer's Mind, tr. Lydia G. Cochrane (Cambridge UK: Polity Press, 2014), ch. 5.
} 
physical one and "scribere" often meant having someone else do the writing. ${ }^{7}$ Similarly in ancient usage the term "autograph" could designate a manuscript vetted by the author or a respected grammarian and thus considered a reliable expression of the author's intention, even if it was written in a hand other than the author's. ${ }^{8}$ Nonetheless even in antiquity dictation had its critics. Quintilian warned that dictated texts required more revision. Jerome worried that someone composing by dictation would be incited to speak whatever occurred to him for fear of falling silent while the secretary was waiting --a sentiment seconded with a different emphasis by Ambrose who praised the extra time for reflection afforded by composing in one's own hand. And Augustine noted that some matters were too delicate to be dictated to another. ${ }^{9}$ Autography held some significance in antiquity too, as evidenced by autograph subscriptions added to scribally produced letters and by occasional references to the autographs of important people. ${ }^{10}$ Suetonius for example spoke of having held compositions of Nero's written in his own hand; an early biography of Augustine reports that his church in Hippo preserved a quire which Augustine had written in his own hand. ${ }^{11}$ The key values of writing sua manu were thus already articulated in antiquity: privacy, control of and more time for composition, and a sense of direct access to the person writing.

\footnotetext{
${ }^{7}$ Mary Carruthers, The Book of Memory: the study of memory in medieval culture (Cambridge: Cambridge University Press, 1992); on "scribere" see Colette Sirat, Writing
} as Handwork. A History of Handwriting in Mediterranean and Western Culture (Turnhout: Brepols, 2006), 442.

${ }^{8}$ David Ganz, "Mind in Character. Ancient and medieval ideas about the status of the autograph as an expression of personality" in Of the Making of Books: medieval manuscripts, their scribes and readers. Essays presented to M. B. Parkes, ed. P.R. Robinson and Rivkah Zim (Aldershot: Scolar Press, 1997), 280-99, p. 298.

${ }^{9}$ See Myles McDonnell, "Writing, Copying, and Autograph Manuscripts in Ancient Rome," The Classical Quarterly n.s. 46: 2 (1996), pp. 469-91 and Quintilian, Institutio oratoria, 10.3.19-21. On Jerome see E. Arns, La technique du livre d'après Saint Jérôme (Paris, 1953), pp. 47-48, quoting the Patrologia latina vol. 25, 1118A. On Augustine, see Pierre Hadot, The Inner Citadel: the Meditations of Marcus Aurelius, tr. Michael Chase (Cambridge MA: Harvard University Press, 1998), p. 33. On Ambrose see Jacqueline Hamesse, "Les autographes à l'époque scolastique. Approche terminologique et méthodologique," in Gli autografi medievali. Problemi paleografici e filologici. Atti del convegno di studio della Fondazione Ezio Franceschini. Erice 25 Settembre-2 ottobre 1990, ed. Paolo Chiesa and Lucia Pinelli (Spoleto: Centro Italiano di studi sull'alto medioevo, 1994), pp. 179-205, p. 188.

${ }^{10}$ See examples from the Vindolanda letters as discussed in Sirat, Writing as Handwork, p. 448.

11 "I have had in my possession notebooks (pugillares) and papers (libelli) with some well-known verses of his [Nero's], written with his own hand and in such wise that it was perfectly evident that they were not copied or taken down from dictation, but worked out exactly as one writes when thinking and creating; so many instances were there of words erased or struck through and written above the lines." Suetonius, Life of Nero, 52.3. Re Augustine, see Sirat, Writing as Handwork, p. 476-79. 
In the middle ages scribing was generally considered a craft and a form of manual labor. In addition to the physical work of writing, the process also involved preparing ink, quill, and writing surface, which was time-consuming and messy too. Writing was not in itself the purview of the scholar. Albert the Great for example described copying in his own hand as an act of humility. ${ }^{12}$ In medieval Paris university students were barred from spending too much time copying. Although they attended sermons at least once daily, they were warned against "wasting time in writing out sermons other than their own; only one day a week might be spent in sermon writing." ${ }^{13}$ We can deduce that the rules against dictating at the University of Paris were observed in the breach given their regular repetition, and they were finally lifted in the 16th century. They likely stemmed in part from a similar sense that mere scribing was a waste of time for university students (though acceptable for younger ones). One master caught dictating justified himself by invoking the poverty of those students who could not afford a scribe and thus needed to make their own copy of the texts. Hiring a scribe was evidently considered the normal solution; at the University of Paris a scribe might be hired to copy from the assigned text deposited by the professor at the stationers' and available for rent in pieces (or "pecia"), thus allowing many copies to be made simultaneously from the same vetted original. ${ }^{14}$ The rare medieval autographs that survive before the 13th century did not seem to carry special weight in their day. For example, a few autograph drafts by Maimonides survive because they were discarded in the Cairo Geniza. ${ }^{15}$ Aquinas autographs only survive from his early years, before he composed by dictating, and his prestige among Dominicans was no doubt crucial to their having been saved. ${ }^{16}$ The significant copy of a work was not the authorial autograph but rather the authoritative exemplar provided for peciation.

Armando Petrucci notes a variety of factors that favored the production and survival of autographs in Italy starting in the 13th century, among them the use of paper and practices of notarial recordkeeping, but also in specific cases the "momentary or

${ }^{12}$ Hamesse, "Les autographes à l'époque scolastique," p. 191.

${ }^{13}$ D. L. d'Avray, Medieval Marriage Sermons. Mass communication in a culture without print (Oxford: Oxford University Press, 2001), p. 26.

${ }^{14}$ István Hajnal, L'enseignement de l'écriture aux universités médiévales (Budapest: Maison d'Edition de l'Académie des Sciences de Hongrie, 1959), 2nd ed., László Mezey (ed.), pp. 121-125. On the "pecia" system see Richard and Mary Rouse, Authentic Witnesses. Approaches to Medieval Texts and Manuscripts (Notre Dame: University of Notre Dame Press, 1991), ch. 8. In Eastern and Central Europe where there was no pecia system, dictation by a bidellus was a common way for students to get copies of their texts; see Hamesse, "Les autographes à l'époque scolastique," p. 197.

${ }^{15}$ Sirat, Writing as Handwork, p. 478. For a very early autograph see Elias Avery Lowe, "An Autograph of the Venerable Bede," Revue Bénédictine 68 \#3-4 (1958), pp. 199-202.

${ }^{16}$ P.M. Gils, "S. Thomas écrivain," in S. Thomae de Aquino Opera omnia iussu Leonis XIII P. M. edita, tome 50 (Rome and Paris: Commissio Leonina, Editions du Cerf, 1992), pp. 173-209. 
prolonged absence of helpers" which motivated writers to write in their own hand. ${ }^{17}$ Petrarch was one of the first to articulate a preference for the autograph and made multiple autograph copies of his work to circulate to avoid the risk of introducing scribal errors (or at least errors made by someone other than himself); but he also employed scribes. ${ }^{18}$ In the first century of humanist recovery of manuscripts, the humanists generally did the copying themselves, whether because the originals were too precious to entrust to others or because of a broader distrust of scribes whose errors and crabbed scripts humanists were on a mission to purge. The humanists famously introduced new scripts modelled on ancient inscriptions and on Carolingian manuscripts which they took to be reproducing ancient forms. Colette Sirat also argues that competition from printing drove professional scribes to promote handwriting as a skill worthy of princes and scholars and successfully used printed manuals to enhance the prestige and visibility of their services. ${ }^{19}$ They were helped in this agenda by humanist pedagogues like Erasmus and Juan Luis Vives who portrayed handwriting as an essential personal skill and a valuable intellectual exercise, citing Quintilian in support.

Erasmus' De recta Graeci et Latini sermonis pronunciatione (1528) offered advice for the teaching of spelling, punctuation and pronunciation, and included a few pages on handwriting. Erasmus blamed the decline of proper handwriting among scholars on printing and highlighted the virtues of writing in one's own hand--privacy, control, evidence of authenticity and personal investment.

Leo: Nowadays the art of printing has led to the situation that some scholars do not write down anything at all! For, if they decide to commit any of their lucubrations to paper, they write so beautifully [ironic] that they themselves cannot read what they have written and require a secretary to read it and decipher what they cannot decipher themselves. ...

To be brief: a letter that is a product of someone else's fingers hardly deserves the name. For secretaries import a great deal of their own. If you dictate verbatim, then it is goodbye to your privacy; and so you disguise some things and suppress others in order to avoid having an unwanted confidant. Hence, quite apart from the problem of the genuineness of the text, no open conversation with a friend is possible here. It is very easy to forge a signature but very difficult to forge a complete letter. A man's handwriting, like his voice, has a special, individual quality. $^{20}$

${ }^{17}$ Armando Petrucci, Writers and Readers in Medieval Italy. Studies in the history of written culture, ed. and tr. Charles Radding (New Haven: Yale University Press, 1995), p. 148.

${ }^{18}$ For an entry into this topic see Chartier, The Author's Hand and the Printer's Mind, p. 77.

${ }^{19}$ Sirat, Writing as Handwork, p. 479.

${ }^{20}$ Erasmus, De recta Graeci et Latini sermonis pronunciatione (1528), as excerpted and translated in A. S. Osley, Scribes and Sources: Handbook of the Chancery Hand in the Sixteenth Century (Boston: David Godine, 1980), pp. 29-30. Cf. "Writing is of the utmost importance in the study which we have under consideration and by its means alone can 
But Erasmus was wary of too much writing, which could lead to bad habits, like developing abbreviations and writing less well. "Leo: ... In former times pupils at school had to take down so much long-hand that boys wrote rapidly but with difficulty, constantly on the look-out for symbols and for abbreviations to save time. ... Ursus: And both these sayings are very true, namely that correct writing leads us to rapid writing, and that it isn't by writing a lot that we come to write well." ${ }^{21}$ In other words, the goal was good elegant writing, and trying to write too much or too fast was a hindrance; the unstated corollary might be that when bulk or speed was required, a helper might offer the best solution.

Juan Luis Vives also promoted learning to write in a dialogue in simple Latin designed for the instruction of boys (Linguae latinae exercitatio, 1538) in which the master tells his well-born charges that the nobility err in spurning "knowing how to do something." Instead "you will attain true nobility if you train your minds with those accomplishments which are particularly appropriate to your noble lineage" --among them handwriting. As the pupils are convinced and the writing lesson begins, a servant is summoned to bring the ink-well. ${ }^{22}$ Writing sua manu would typically take place with the help of a servant.

Writing masters used their skills and the new medium of printing to raise writing up from its status as a mechanical activity. Osley has identified some twenty handwriting manuals printed in the 16th century, most of which went through multiple editions, offering not just models of writing to imitate but a full treatise on handwriting (e.g. on preparing and holding the quill, forming the letters in different scripts, the joins, the slope etc) which frequently opened with a justification for learning these skills. ${ }^{23}$ Some masters emphasized that bad handwriting would make a reader ill disposed to the arguments

true and deeply rooted proficiency be obtained. But a sluggish pen delays our thoughts, while an unformed and illiterate hand cannot be deciphered, a circumstance which necessitates another wearisome task, namely the dictation of what we have written to a copyist. We shall therefore at all times and in all places, and above all when we are writing private letters to our friends, find a gratification in the thought that we have not neglected even this accomplishment." Quintilian, Institutio oratoria, tr. Harold Edgeworth Butler (Cambridge MA: Harvard University Press, 1958), 1.1.28-29.

${ }^{21}$ Osley, Scribes and Sources, pp. 29-30.

${ }^{22}$ Osley, Scribes and Sources, pp. 41-42. Interestingly the mention of the servant is not present in the edition of Vives' work from Edinburgh, 1657.

${ }^{23}$ Forty such manuals from the 16th century, in addition to others in the 17 th are listed in David Becker, The Practice of Letters. The Hofer Collection of Writing Manuals 15141800 (Cambridge MA: the Harvard College Library, 1997). For a focus on English writing manuals see Ambrose Heal, The English writing-masters and their copy-books, 1570-1800: a biographical dictionary \& a bibliography (London: First Edition Club, 1931); and Simran Thadani, "'For the Better Atteyning to Faire Writing': An Analysis of Two Competing Writing-Books, London, 1591," Papers of the Bibliographical Society of America 107:4 (2013), pp. 422-66. 
contained in the letter; conversely a good hand would predispose the reader favorably. ${ }^{24}$ In the most ambitious such statement, the Basque Pedro de Madariaga who dedicated his Libro subtilissimo to Philip II in 1565, called handwriting a liberal art, because it opened the way to higher disciplines and was an appropriate pursuit for a gentleman along with fencing, swimming, and dancing. Penmanship should even, he went further, "be given a place among the supreme accomplishments and inspired sciences close to holy Theology" since it was a divine gift and God himself was a scribe, have written in his own hand the tablets of the law that he gave to Moses. ${ }^{25}$

In another line of argumentation the Spaniard Andres Brun proposed to correct Plato by emphasizing that writing, not speech was the most distinctive human skill. ${ }^{26}$ This notion coincided with the Spanish imperial project too. A recent study of Yciar's Recopilación subtilissima (1548) has emphasized that handwriting was essential to the conduct of imperial administration and information-gathering with its vast accumulation of manuscripts, most of which were never printed. But for Brun and others, writing was also taken as a clear sign of European superiority over the inhabitants of the Americas. Even Jose de Acosta who was among the most favorably curious about them ("there are no people so barbaric that they do not have something worthy of praise") noted that the Indians did not have the use of letters, only of signs that signify things. ${ }^{27}$ If writing was a uniquely human skill, then the absence of writing was an argument for the less than human standing of the natives of the Americas (though that argument required ignoring the successful instruction of natives in Latin in the early days of the College of Santa Cruz). ${ }^{28}$

While writing masters generally addressed their works to the highest social ranks in search of the best possible patronage and visibility, some of them also noted the value of their art for the less well born: through writing men "of lowly birth can ... improve themselves and not envy [those above them in society]; they can walk with their heads high, proud to realise that, without this accomplishment, even men of superior quality cannot ennoble themselves or appear in the ranks of the noble." Secretarial skills no

${ }^{24}$ Giovan Francesco Cresci, Il Perfetto Scrittore (1570), in Osley, Scribes and Sources, p. 118.

${ }^{25}$ Osley, Scribes and Sources, p. 155.

${ }^{26}$ Osley, Scribes and Sources, p. 180; cf. Sirat, p. 106.

${ }^{27}$ José de Acosta, Natural and Moral History of the Indies, tr. Frances López-Morillas, ed. Jane Mangan (Durham and London: Duke University Press, 2002), book 7, p. 379 and ???; re Yciar and imperialism, see Jessica Berenbeim, "Script after print: Juan de Yciar and the art of writing," Word and Image, vol. 26, no. 3 (July-Sep. 2010), pp. 231-243.

${ }^{28}$ For an entry into this topic see Walter Mignolo, "On the Colonization of Amerindian Languages and Memories: Renaissance Theories of Writing and the Discontinuity of the Classical Tradition, Comparative Studies in Society and History 34 (1992), pp. 301-30. On the Mexican colleges see Andrew Laird, "Latin in Cuauhtemoc's shadow: Humanism and the Politics of Lang in Mexico after the Conquest" in Latinity and Alterity in the Early Modern Period, ed. Yasmin Haskell and Juanita Feros Ruys (Tempe AZ: ACMRS and Turnhout: Brepols, 2010), pp. 169-200. 
doubt proved a means of upward mobility for many, though these trajectories can be hard to document, because few who rose in the social hierarchy cared to call attention to their low birth. Osley points to one exceptional trajectory, in Thomas Wolsey's rise from butcher's son to Lord Chancellor, fueled by his secretarial skills. Of the writing masters Osley discusses most were born to families of means or even noble standing. But a few whose origins are unknown, like Juan de la Cuesta of Alcalá described as coming from a tiny village in Guadalajara, might themselves represent cases of upward mobility. ${ }^{29}$

Of course the writing masters were engaged in a campaign to sell their books and their services as teachers, in more or less direct competition with one another, and to raise the status of their activity. It is hard to document their impact independently of other factors such as the spread of humanist education, the rise of bureaucracies and of literacy. The genre of printed book that the masters developed, which used woodblock then copper engraving to reproduce all kinds of handwriting, continued to grow in the 17th century (including many shorthand manuals in England especially). Although it would be hard to quantify, it seems clear that the increased production and survival of manuscripts in the early modern period also involved greater percentages of autography, in part as a result of the impact of writing masters and their publications.

\section{DELEGATION IN LETTER-WRITING}

The genre in which attitudes toward autograph versus scribal writing have best been studied is correspondence. In his analysis of over 10,000 English letters from 1512-1635 James Daybell notes a growing expectation during this period of writing in one's own hand letters to family, friends, and associates, detectable from practice and from apologies for failing to do so. Letters written by scribes were preferred for more formal letters relating to government, law, or business. Letters to the monarch were scribal, for example, because autographs would be too familiar, except from those writing from special positions of favor or intimacy. Daybell notes that it is unclear how far down the social scale this convention extended, beneath the rank of monarch. It was common also to write to social inferiors using a secretary. Additional gender conventions likely existed; for example it may have been deemed inappropriate to write personally to a woman to whom one was unrelated or unknown, and vice versa. ${ }^{30}$ Autograph subscriptions to scribal letters enabled writers to add a personal message, as a sign of affection or to preserve confidentiality. These reasons for autography are all familiar from antiquity.

New in the 16th century was the interest in collecting autographs: first in the album

${ }^{29}$ Augustino da Siena, Opera nella quale si insegna a scrivere (ca. 1565) in Osley, Scribes and Sources, p. 103. Re Wolsey and Juan de la Cuesta, see Osley, pp. 103 and 173.

${ }^{30}$ James Daybell, The Material Letter in Early Modern England. Manuscript letters and the culture and practices of letter-writing 1512-1635 (Palgrave Macmillan, 2012), 86-88; and Daybell, "The social conventions of women's letter-writing in England, 1540-1603," in Daybell (ed.), in Early Modern women's letter-writing in England, 1450-1700, pp. 5976. 
amicorum tradition, then in occasional collections of correspondence that seem focused on gathering autograph letters by prominent people (notably a volume formed by the antiquarian and Parliamentarian Sir Simonds d'Ewes, 1602-50). Munby concludes that for most antiquarians the autograph status of manuscripts was incidental, but Samuel Pepys had one of his secretaries (probably Paul Lorrain) make careful facsimiles of signatures copied from the State Papers in a "Repertorium chiro-typicum" which could then be used to test whether papers in his collection were originals or transcripts. ${ }^{31}$ The rise of the signature as a mark of authentication was a gradual one from the middle ages when signatures were accompanied by seals and personal appearances to the 18 th when an author's signature was sometimes added to the title page of a book to authenticate the copy (as in Tristram Shandy or Hoyle's Book of games).

Despite the rise of autography early modern letter-writing more often than not involved the work of another: family members could write for one another; friends could be consulted or involved, but most commonly professionals were engaged, at the highest levels even in complex hierarchies of secretaries with different specialties. Daybell concludes nonetheless that it is hard to establish exactly what happened in each case: "letters might be dictated, either verbatim or partially, leaving the scribe to provide opening and closing modes of address; they might be written from notes, penned from oral instructions or derived from epistolary models and templates; their invention might also be entirely ghosted by a secretary." 32 Scribes were also tasked with copying outgoing letters for the sender to keep as record, or in order to circulate them to additional readers in manuscript. ${ }^{33}$ Social conventions and practical considerations fed a constant interaction between writer and helper in the production of the vast quantity of manuscript comprised by early modern letters.

\section{DELEGATION IN NOTE-TAKING}

In turning to note-taking, we face many of the same interpretive problems as we do for letter-writing, and without as much existing synthetic work. Note-taking could serve different purposes: as a method and record of one's reading, as material to share with others, or from which to compose a new publication. Helpers could be involved at every stage in multiple ways, though explicit mention of scribal help was typically limited to just a few activities, such as making clean copies and taking dictation.

\footnotetext{
${ }^{31}$ A. N. L. Munby, The Cult of the autograph letter in England (London: Athlone Press, 1962), 1-3.

32 Daybell, Material Letter, p. 79; see also Daybell, "Women's letters and letter-writing in England, 1540-1603: an introduction to the issues of authorship and construction," Shakespeare studies 27 (1999), 161-86.

${ }^{33}$ Daybell notes that the letter should not be considered a single text, given the number of different versions that may have existed and that survive: "drafts were later reworked; secretarial copies kept as records, as separates or in formal letter-books; neat copies were produced for presentation; and transcripts made for wider circulation in manuscript." Daybell, Material Letter, p. 74
} 
It is not easy to tell who did what amid surviving papers. Daybell emphasizes that masters and their amanuenses, and even women, long thought to have generally learned just one script, might move between two (or more) scripts depending on the language, the genre and the circumstances of their writing. So it's not easy to identify the same person writing in two different scripts. Conversely secretaries were also encouraged to mimic their master's hand--and this was not considered duplicitous. ${ }^{34}$ But presumably secretaries tended to have clear, neat hands. Paul Nelles suggests that Gabriel Naudé in the employ of various French grandees was given the task of forming and organizing libraries rather than copying because of his poor handwriting--a failing that Naudé was perhaps not displeased with given his likely preference for work in libraries. ${ }^{35}$ Whereas as Vives mocked as being uncultured nobles whose signatures were illegible, might a messy hand have also served as a sign of social standing, of not having to conform to the needs of legibility? A difficult hand might thus safely be identified as the master's hand and historians encounter plenty of those--Ulisse Aldrovandi, Nicolas Fabri de Peiresc, and Theodor Zwinger among them. In a printed index marked up by Erasmus and his amanuensis Nicolaus Cannius, the latter's hand is predictably the neater hand. ${ }^{36}$ But no doubt masters occasionally used neat hands too. Conrad Lycosthenes for example gave his notes to his stepson Theodor Zwinger as a seed from which the latter grew his Theatrum humanae vitae (1565). The surviving slips that match Lycosthenes' ex-libris inscription are neat and sorted by headings, unlike other slips in the Zwinger papers (which I have presumed to be Zwinger's own). Perhaps Lycosthenes took these notes neatly himself or perhaps he had them copied before passing them on to Zwinger. ${ }^{37}$ After all, proficient writers surely varied their level of neatness. We can observe that Conrad Gessner wrote very neatly when inscribing gift copies of his books, and much less so when annotating his books for his own use. So conclusions about who wrote what in surviving collections of papers must often remain somewhat speculative. ${ }^{38}$

The theorists of note-taking, humanist then Jesuit pedagogues, generally emphasized the importance of taking notes in one's own hand, as an exercise in retaining the best bits of one's reading. Petrarch was one of the first to articulate the notion that one should not read without writing at the same time: "I do not read without writing. ... Because writing

${ }^{34}$ H. R. Woudhuysen, Sir Philip Sidney and the Circulation of Manuscripts 1558-1640 (Oxford: Clarendon Press, 1996), 388.

${ }^{35}$ Paul Neave Nelles, "The Public Library and Late Humanist Scholarship in Early Modern Europe: antiquarianism and encyclopaedism," PhD Johns Hopkins University, 1994, p. 219.

${ }^{36}$ Luigi Michelini Tocci, In officina Erasmi : l'apparato autografo di Erasmo per l'edizione 1528 degli Adagia e un nuovo manoscritto del Compendium Vitae (Rome: Edizioni di storia e letteratura, 1989), figure 7.

${ }^{37}$ For some illustrations see Blair, Too Much To Know: managing scholarly information before the modern age (New Haven: Yale University Press, 2010), pp. 215-16.

${ }^{38}$ Compare for example the inscription by Gessner to Heinrich Bullinger in the copy of Evonymi thesaurus (1552), Zentralbibliothek Zurich, call number Md E 377, digitized on E-rara, with the notes in Gessner's own copy of his Bibliotheca universalis (1545), Zentralbibliothek Zurich, call number DrM3, digitized on E-rara. 
is slower than reading, the more deeply it is impressed and the more tenaciously it sticks [in the mind]." ${ }^{39}$ Note-taking was thought to aid the memory in two different ways: not only by creating a written record to return to, but also by forcing the mind to dwell on the material and to retain better what was read or heard by writing it down. Francesco Sacchini and Jeremias Drexel, the Jesuit authors of the two most reprinted manuals on note-taking, made this point repeatedly. ${ }^{40}$ In support of the pedagogical virtues of writing Sacchini cited the model of ancients who copied texts not in order to have copies of them, but in order to retain them better. He reports (with what veracity I do not know) that Demosthenes copied Thucydides eight times, and Saint Jerome wrote many volumes in his own hand, "not due to the weakness of his library but out of desire to profit from the exercise. ${ }^{41}$ The sentiment was widely shared by other pedagogues, from Juan Luis Vives who also praised the act of copying for keeping light or scabrous thoughts at bay ${ }^{42}$ to New England preacher Richard Steele who wrote in 1682: "the very writing of any thing fixes it deeper in the mind." ${ }^{43}$

39 "Nihil legi nisi dum scriberem ... Quod enim tardior est scriptura quam lectio, eo altius imprimitur haeretque tenacius." Petrarch, Epistolae de rebus familiaribus (Florence: Felicis Le Monnier, 1862), XVIII, 12, pp. 498-99, as discussed in Hamesse (1994), p. 204.

40. E.g. "Deinde ipsa quoque scriptio et intelligentiam iuvat." Francesco Sacchini, De ratione libros cum profectu legendi libellus (Ingolstadt: ex typographo Ederiano, 1614), p. 74. Or "excerpendum esse diversis rationibus docetur. Prima est: lectoris intentio scribendi et annotandi cura multum acuitur. Altera ratio est: quod exscribitur, intelligentiam profundius subit, menti altius imprimitur. ... Cum gnaviter excerpit et annotat, crebrius subsistere cogitur et pedem figere: etiam dum lectis immoratur, dum relegit et retractat, longe melius, quae retinenda penetrat." Jeremias Drexel, Aurifodina artium et scientiarum omnium; excerpendi sollertia, omnibus litterarum amantibus monstrata (Antwerp: vidua Ioannis Cnobbari, 1638), ch. 9, p. 56. For more on Sacchini and Drexel, see Blair, Too Much To Know, ch. 2.

41."Itaque Demosthenes sua manu si Dionysio Halicarnasseo credimus, octies totum exscripsit Thucididem. Multa etiam manu sua exscripsit volumina S. Hieronymus: multa alij sapientissimi viri, non tam librarij inopia, quam cupiditate profectus ex opere." Sacchini, De ratione ... legendi, p. 74.

42.Ann Moss, Printed Commonplace Books and the Structuring of Renaissance Thought (Oxford: Clarendon Press, 1996), quotation \#125.

43.Richard Steele, "What are the Hindrances and Helps to a Good Memory in Spiritual Things?" in Samuel Annesley (ed.), A Continuation of Morning-Exercise Questions ... resolved in 1682, (London: J.A. Dunton, 1683), p. 428, as quoted in Thomas Knoles and Lucia Zaucha Knoles, "In Usum Pupillorum: student-transcribed texts at Harvard College before 1740," in Thomas Knoles, Rick Kennedy and Lucia Zaucha Knoles, Student Notebooks at Colonial Harvard: Manuscripts and Educational Practice 1650-1740 (Worcester: American Antiquarian Society, 2003), pp. 7-88, p. 57. I also discuss this in my "Textbooks and Methods of Note-Taking in Early Modern Europe," in Emidio Campi, Simone de Angelis, Anja-Silvia Goeing and Anthony Grafton (eds.), Scholarly Knowledge: Textbooks in Early Modern Europe (Geneva: Droz, 2008), pp. 39-73. 
In this spirit students were expected to do a lot of writing, not just while reading material for the first time (when it would increase attentiveness to the text), but also by copying notes a second time. Sacchini called for students to copy out each excerpted passage twice, first in a notebook kept in the order in which items were read, then in a notebook sorted by commonplace headings. Delegation would deprive the student of the additional opportunity for retention through writing and Sacchini did not even discuss the possibility. In various contexts teachers also assigned their students to copy out the notes or a text composed by another. Anthony Grafton and Urs Leu have recently documented how the Swiss humanist Heinrich Glarean taught chronology by having his students copy out the marginal notes in his copy of an assigned work. This practice of copying marginal annotations would also explain the multiple copies of technical works like Copernicus' De Revolutionibus containing near identical annotations. ${ }^{44}$ At Harvard College in the late 17 th century students were assigned to copy out manuscript textbooks brought from England; they did so in installments throughout the semester. There were insufficient numbers of students to warrant printing the text, and the pedagogical virtues of copying were assumed. But in these cases one of the purposes was also to create a new copy of the notes or the text. I am not aware of rules forbidding hiring someone to do this work in one's stead. One could take this as a sign that this copying was supervised by a master and could not be evaded or delegated; but perhaps delegation was allowed or did happen in some circumstances. Outside a pedagogical context, making a copy of a text not otherwise available, whether a manuscript or a printed book, was certainly something likely to have been requested of secretaries in various circumstances. $^{45}$

Beyond these conservative pedagogical circles another line of advice assumed that scholars and even students would rely on the work of others to some extent. The principal point in these recommendations was to establish what work could usefully be delegated, by distinguishing the tasks requiring judgment which should redound to the master, from more mechanical activities of taking dictation or copying which could safely be delegated. Taking as a model Pliny who was read to and dictated large numbers of notes (according to the account of his nephew), Guarino da Verona (1374-1460) suggested that in studying, a young nobleman might hire a servant to copy out excerpts into his notebook, but the master would select the excerpt and dictate it. ${ }^{46}$ Similarly a 1599 letter to Fulke Greville (possibly by Francis Bacon) advises the new Cambridge student to hire "two or three ... to gather for you" (including possibly a friend), but they should be told to gather examples and arguments

\footnotetext{
${ }^{44}$ Anthony Grafton and Urs Leu, "Chronologia est unica historiae lux: How Henricus Glareanus Studied and Taught the Chronology of the Ancient World," in Iain Fenlon and Inga Mai Groote (eds.), Heinrich Glarean's Books. The Intellectual World of a SixteenthCentury Musical Humanist (Cambridge: Cambridge University Press, 2013), pp. 248-79. On Copernicus see Owen Gingerich, An annotated Census of Copernicus' De revolutionibus (Nuremberg, 1543 and Basel, 1566) (Leiden: Brill, 2002), pp. xix-xxi, concerning the notes copied by the students of Jofrancus Offusius.

${ }^{45}$ On manuscript copies of printed books see my "Reflections on technological continuities: Manuscripts copied from printed books," Bulletin of the John Rylands

Library 91:1 (2015), pp. 7-33.

46. Moss, Printed Commonplace Books, p. 54.
} 
relevant to a position or question of the master's selection. ${ }^{47}$ The letter warns that "one Man's Notes will little profit another, because one man's Conceit doth so much differ from another's; and also because the bare Note itself is nothing so much worth, as the suggestion it gives the Reader." A note taken by another could not trigger a personal recollection of reading and therefore required establishing ahead of time strong criteria for the note-taking and maintaining constant interaction between the note-taker and the person for whom the notes were taken. "For [your Collectours] should like labourers bring Stone, Timber, Mortar and other Necessaries to your Building: But you should put them together, and be the Master-workman yourself." ${ }^{48}$ In this conception the master could impart precise instructions for others to follow, with proper supervision.

Francis Bacon was skeptical that judgment could be delegated successfully so recommended limiting the practice to unimportant material: "some books also may be read by deputy and extracts made of them by others, but that would be only in the less important arguments and the meaner sort of books." ${ }^{49}$ Drexel the Jesuit was also dubious about delegating judgment. "Notae propriae, notae optimae": "your own notes are the best notes," he explained, with one page of the former being worth " $10,20,100$ pages" of the latter. Hence his displeasure too in the reliance on reference books which presented in print the reading notes of others. ${ }^{50}$ But some fifty years later Daniel Georg Morhof took a frankly positive attitude toward delegation: "If you can afford it, you should employ learned amanuenses, to whom to assign the task [of taking notes lemmatice]; but who use your judgment in collecting, as Saumaise and other very eminent men have done. ${ }^{, 51}$ Morhof gives no further advice on how to lead an

${ }^{47}$ On the contested authorship of this letter which echoes themes found elsewhere in Bacon's writings, see Alan Stewart with Harriet Knight (eds.), The Oxford Francis Bacon, vol. 1: Early writings 1584-1596, (Oxford: Clarendon Press, 2012), pp. 207-212, at pp. 200-205. Concerning the status of friends, care was taken to treat their help differently from that of secretaries; see Paul E.J. Hammer, "The Earl of Essex, Fulke Greville, and the employment of scholars," Studies in Philology 91 (1994), pp. 167-80 concerning the treatment of Bacon.

${ }^{48}$ Vernon F Snow, "Francis Bacon's Advice to Fulke Greville on Research Techniques," Huntington Libary Quarterly 23 (1960), pp. 369-78, at 374 (370 re friendship); and Hammer "The Earl of Essex."

${ }^{49}$ Francis Bacon, "Of studies" in Brian Vickers (ed.), Essays in Francis Bacon. The Major Works, (Oxford: Oxford University Press, 2002), p. 439.

50. "Hic ego cum cochlea velut oraculum proloquor: Domus propria, domus optima: Notae propriae, Notae optimae. Unica Excerptorum pagina tuo labore scripta, magis tibi erit usui quam decem, quam aliae viginti, quam aliae centum, quas diligentia obtulerint aliena." Drexel, De aurifodina, p. 58. "Quam multa sunt, quae scriptores alii, aut studio praetermittunt, aut incuriosi transeunt, aut ad alia festinantes negligunt, aut reperta mutilant et frangunt? quae attentus lector, hinc illinc ingenti suo commodo decerpet." Drexel, De aurifodina, p. 59.

51. "Vel si opibus non destituaris, amanuenses alas non ineruditos, quibus rem illam [taking notes lemmatice] committas; sed qui tuo judicio in colligendo utantur. Id Salmasius aliique viri praestantissimi fecerunt." Daniel Georg Morhof, Polyhistor, 3rd ed. (Lübeck: Petrus Boeckmannus, 1732), I, 1, 21 \#12, p. 239. 
amanuensis to replicate his employer's judgment. Kevin Sharpe argues that the papers of Sir William Drake offer an example of that kind of success: the fifteen commonplace books in Drake's own hand (composed from 1627 to the mid-1640s) are followed by twenty-two volumes of notes mostly in another hand, but using similar headings, authors, and judgments, which suggests that Drake successfully conveyed to his amanuensis his methods of working and selecting, presumably by interacting closely with him during the process. ${ }^{52}$ For this strand of advice-givers delegation was acceptable only on points of lesser importance (Bacon) or if judgment involved was exercised by the master himself or in close consultation with him.

The case of Gabriel Harvey shows that extensive note-taking that was delegated to professional readers in elite political circles in early seventeenth-century England. Harvey not only summarized but also reflected on the lessons to be drawn from the histories of Livy in his copy of the book annotated for the use of his employer, the earl of Leicester. ${ }^{53}$ We can wonder how closely directed his reading was by preliminary instructions or regular discussions during the process of reading. But more likely Harvey's role resembles that of the scholars hired by Robert Devereux, second Earl of Essex, studied by Paul Hammer, who sought to hire the best university graduates precisely in order to delegate to them the task of expert judgment. ${ }^{54}$ In these cases a high-ranking employer sought the help of men who were his social inferiors but offered exceptional intellectual skills and background. He hired them not for mechanical tasks like copying but in order to benefit from their well-trained judgment and university education. In this context an elite family could be mocked on the contrary for hiring only "base pen clerks that can do nothing but write as they were bidden," a charge that was levelled after his death against Elizabeth's chief minister Burghley and his son. ${ }^{55}$

A final model of reliance on the notes of others occurred in the context of collaborative note-taking among peers. Bartholomaeus Keckermann is credited by Vincent Placcius (in De arte excerpendi, 1689) with first devising methods of group study. Keckermann advised that three students of similar age, ability, and interests, would work together to master texts, by taking turns reading aloud while the other two took notes or by pooling notes they each took on different themes if they hired a reader to read for them. ${ }^{56}$ Placcius invoked this

52 Kevin Sharpe, Reading Revolutions: The Politics of Reading in Early Modern England (New Haven: Yale University Press, 2000), pp. 273-74.

53. Lisa Jardine and Anthony Grafton, "Studied for Action: How Gabriel Harvey Read his Livy," Past and Present 129 (1990), pp. 30-78.

${ }^{54}$ See Hammer, "The Earl of Essex."

${ }^{55}$ Woudhuysen, Sir Philip Sidney, p. 83.

56 "Socialium Excerptorum primus mentionem, quod sciam, fecit KECKERM. Cons. Log de adornandis Locis Communibus c.1. p. 3. columna 2. circa finem: exponens, quomodo plures conjungere possent operam suam in excerpendo." Vincent Placcius, De arte excerpendi_(Stockholm and Hamburg: Gottfried Liebezeit, 1689), p. 161. This is likely the passage Placcius had in mind: "Socius modus est, quando coniunguntur opere, tum in legendo tum in colligendo id quod hac ratione maxima cum utilitate fiet; 1 . si coniungerent se tres studiosi similium ingeniorum et parium profectuum. 2 . si isti tres 
model in praising the virtues of the note closet he describes from the 1640s manuscript of Thomas Harrison: the closet is the ideal tool for a group of scholars to share their notes with one another. Placcius also describes what could be delegated to a "third party" in the use of the closet-- a servant could file note slips to their proper place after use (and presumably fetch them too). ${ }^{57}$ These forms of collaboration among peers who shared a same purpose resembles the dispersed sharing of notes that can be tracked through correspondence networks in the Republic of Letters, when scholars circulated to one another results of their reading, observations, and thinking in response to queries or in exchange for similar gifts. Gesner's accumulation of notes in the "Thesaurus practicae medicae" shows for example how he integrated the contributions of others, by cutting and pasting from their letters, into categories of his choosing. The manuscript survives because though it was prepared for publication, it was never published--presumably the next step would have been to commission a clean scribal copy. In its absence we have three folio volumes comprising slips cut and pasted from letters, manuscripts, and printed books in an innumerable number of hands. ${ }^{58}$

In letter-writing autography was valued for the control, the privacy, and the personal gesture involved. In note-taking autography was valued by some for the intellectual mastery it fostered and by all for the personal control of judgment that notes represented. Unlike autograph letters designed to be read by others, autograph notes were more likely to be taken in haste and bad writing for personal use, so notes to be shared with others might result from copying out by a helper in a neat hand.

\section{ACKNOWLEDGMENTS OF DELEGATION}

The work of helpers becomes visible occasionally, in private correspondence, or in print to apologize for their errors or other failings. The invisibility of intellectual helpers is not surprising given the broader cultural system in which households functioned thanks to the

eundem scopum haberent propositum, et essent vel studiosi Theologiae omnes, vel Politicae et Iuris, vel aliarum etiam facultatum. 3. si sint aeque diligentes et industrij. 4. si sint sibi invicem addicti et amici; ita, ut alter sine invidia alteri suam sententiam velit communicare. 5. si alant aliquem anagnosten, sive lectorem, aut si non possint alere lectorem, ipsi per vices hanc operam praestent. 6 . Habeant volumina iam parata, in quibus ea, quae notatu digna sunt, notent. 7. Notare autem poterit unus e numero per vices, sed ita, ut in dubiis aut obscuris, quando non ita statim liquidum est, ad quem titulum referri aliqud debeat, sententias inter se conferant. 8. volumina illa communia deinde a singulis describi poterunt, vel etiam poterit hic modus commodior observari, ut duo qui non legunt, suis distincits voluminibus sibi notent, tertius qui legit, postea sibi notet, aut si anagnosten alunt singuli singulis voluminibus possunt notare, breviter, si opus sit, collatis sententiis." Bartholomaeus Keckermann Opera omnia (Geneva: Aubertus, 1614), vol. 2, col. 222-23 (misnumbered 220-221).

57 "Quo casu etiam per tertiumquemque postea poterunt suis locis in scrinio appendi." Placcius, De arte excerpendi, p. 156. On the origins of the text see Noel Malcolm, "Thomas Harrison and his 'Ark of Studies': An Episode in the History of the Organization of Knowledge," Seventeenth Century 19 (2004), pp. 196-232.

${ }^{58}$ Blair, Too Much To Know, pp. 216-19. 
labor of servants of many kinds who were treated as invisible. In addition, I suspect, the notion of an author's talent was sufficiently developed that there was something to be lost in acknowledging the contributions of helpers of lower status. Conrad Gessner offered explicit thanks far more often than most contemporaries, acknowledging and thus also encouraging the contributions of specimens, images, or information to his natural histories and other projects. But Conrad Gessner only thanks peers (typically scholars, physicians or pharmacists) or patrons in the Republic of Letters, not the amanuenses whom we know he also employed. ${ }^{59}$ Gessner has left fleeting evidence of these helpers in his Bibliotheca universalis and his correspondence: in the first work he apologizes for excessive prolixity caused by his amanuenses (in the plural) and in a late letter he solicits suggestions of a studious young man who could work for him. ${ }^{60}$ When even a Gessner, who was exceptionally generous in his expressions of thanks, never acknowledged his amanuenses, it is not surprising that other contemporaries did not do so either.

Despite the general silence about the role of helpers in scholarly work, a few tasks were mentioned explicitly in public contexts as being appropriate to delegate. Presumably these tasks seemed good to delegate because they were both mechanical and tedious--in particular alphabetizing and indexing, taking dictation and making a clean copy for the printer. Alphabetizing was explicitly called mechanical work in Juan Caramuel's 1664 description of how to cut up and distribute slips alphabetically to create an index: "have someone cut up [the sheets containing the index entries] with scissors into slips (lemmata): have someone do this, I say, do not do it yourself: indeed this work is mechanical. ... Call four or six servants or friends and have them distribute the slips by letter and classes." ${ }^{61}$ Sorting according to

${ }^{59}$ On Gessner's thanking practices see my "The dedication strategies of Conrad Gessner," in Cynthia Klestinec and Gideon Manning (eds.), Professors, Physicians and Practices in the History of Medicine: Essays in Honor of Nancy Siraisi, forthcoming Springer and "Conrad Gessner : publicité et gestion des savoirs," in Annie Charon, Isabelle Pantin and Sabine Juratic (eds.), L'Annonce faite au lecteur, forthcoming.

60 "Caeterum non diffiteor argumenta vel capita librorum aliquot, verbosius quam vellem explicata mihi displicere: sed illud maxime in primo elemento commisi amanuensium opera usus, in caeteris nolim brevior fuisse." Conrad Gessner, Bibliotheca universalis (Zurich: Froschauer, 1545), sig. *4r. "Postremo scire a te cupio, an invenire possem apud vos aliquem iuvenem aut adolescentem mediocriter instructum literis, medicinae studiosum, pauperem, modestum et bonum: qui mihi scribendo ac describendo navaret operam: posset interim lectionem unam aut alteram publicam audire: et domi apud me obiter in mensa et alias proficere." Gessner to Zwinger, April 8, 1565 in Gessner, Epistolae medicinales (Zurich: Froschauer, 1577), ff. 111v-112r. I am grateful to Candice Delisle for this lead.

61 "Tertio, singula lemmata forficibus secari jube. Jube dico, non Fac: nam labor iste est mechanicus, nec te indiget: sufficiet enim, ut alios dirigas. ... Quinto, quatuor aut sex famulos aut amicos advoca, et lemmata jube per literas et classes distribui." Juan Caramuel Y Lobkowitz, Theologia praeterintentionalis.. est theologiae fundamentalis tomus IV (Lyon, 1664), pp. 185-200, in V. Romani, Il "Syntagma de arte typographica" di Juan Caramuel ed altri teste secenteschi sulla tipografia e l'edizione (Manziana: Vecchiarelli editore, 1988), pp. 1-73, p. 30. 
explicit criteria like the alphabet (or the headings noted on slips for the note closet, as mentioned above) could be delegated to friends or servants without special training. Similarly, but only in manuscript, Ulisse Aldrovandi thanked his wife for gluing slips into place in his multi-volume encyclopedia left in manuscript, the "Pandechion epistemicon."62 Alphabetizing was a key component of indexing, which was also mentioned in print as work performed by an amanuensis, notably in a poem praising Gilbert Cousin's work for Erasmus. ${ }^{63}$ Erasmus was also sometimes personally involved in indexing too, as is clear from surviving manuscripts bearing some annotations by Erasmus alongside the more numerous additions by his amanuensis to prepare the index for a new edition of the Adages. ${ }^{64}$ Unlike alphabetizing tout court indexing certainly involved judgment in selecting what to index and under what heading.

In the few relevant images we have from the 16th and 17th centuries, secretaries are typically shown taking dictation. For example in a 1553 pamphlet celebrating his relationship with Erasmus among other highlights of his career Gilbert Cousin depicted himself working with Erasmus as a young man some 20 years earlier, taking dictation; in 1668 Jacob van Oost's portrait of a theologian includes a secretary taking dictation. But few early modern scholars or authors discussed composing by dictation. On the contrary some may have hidden that method of working. George Hoffman suspects that Montaigne composed parts of his Essais by dictation, but Montaigne never made mention of it, though he discusses introspection, reading, and writing aplenty. ${ }^{65}$ Montaigne emphasized instead the solitude of his study and reflection, although many servants attended him, including likely when he was writing. It is likely that the growing value associated with autography in the early modern period made dictation no longer seem an ideal method of composition. Authors who mentioned composing by dictation might explain that a physical disability necessitated it, as Robert Boyle did, invoking a persistent eye ailment. ${ }^{66}$

${ }^{62}$ See Paula Findlen, "Masculine Prerogatives: Gender, Space, and Knowledge in the Early Modern Museum," in Peter Galison and Emily Thompson (eds.), The Architecture of Science (Cambridge, MA: MIT Press, 1999), pp. 29-57, p. 44 and note 62.

Aldrovandi's wife was also very well educated, as can be judged by her signing a Latin dedication to her husband's posthumously published De reliquis animalibus exanguibus (Bologna: Baptista Bellagamba, 1606). I am grateful to Caroline Duroselle-Melish for pointing this out to me.

${ }^{63}$ For the image see Blair, Too Much To Know, p. 107. For the poem: "Iodocus Sabutus Caesaris consiliarius, in Gilberti Cognati Nozereni librum Flosculorum ex omnibus Eras. Rot. operibus summo labor selectorum: Qualis erat quondam vivo Cognatus Erasmo,/ In pia defuncti talis et ossa manet./ Ut bibulas pinxit chartas, dictante magistro:/

Sic iam selectos colligit inde locos./ Illud erat pietatis opus, studiique perennis: / Hoc verae firmus relligoinis amor." Effigies Des. Erasmi Roterodami et Gilberti Cognati Nozereni, eius amanuensis. Accesserunt et doctorum aliquot virorum in D. Erasmi et Gilberti Cognati laudem carmina (Basel: Oporinus, 1553), p. 29.

${ }^{64}$ See note 36.

${ }^{65}$ See George Hoffmann, Montaigne's Career (Oxford: Clarendon Press, 1998), p. 48ff.

${ }^{66}$ Robert Boyle, New Experiments Physico-Mechanical, Touching the Spring of the Air and its Effects (London: Miles Flesher, 1660), sig. [A4]v. 
Even while autography was increasingly valued during this period, one kind of delegated copying was considered virtuous--having a clean copy of a manuscript made for the printer. For example, we know from letters and the multiple hands in surviving papers that the famous Florentine humanist Piero Vettori (1499-1585) worked with a group of helpers, including some of his students, his son Jacopo, and in due course his grandson Francesco. And yet in his éloge of Piero after the latter's death Francesco boasted that his grandfather, unlike most humanists, worked alone, relying only on a single copyist occasionally to make a clean copy for the printer. ${ }^{67}$ The one best placed to know Piero's working methods obscured them. Just as a modern editor might deny playing a substantive role in part in order to preserve his relationship with the author, here the helper preferred to elevate his grandfather to the status of an exceptional humanist instead of calling attention to his own bit part in his scholarship. ${ }^{68}$ But even given his concern to efface his own help and that of others, Francesco mentioned the hiring of a scribe to make a clean copy. Francesco turns this act of delegation into a further point of praise of the deceased scholar. Indeed many a printed errata list cast blame on the author for providing a messy manuscript from which to set type, thus incurring errors for which the printer denied responsibility. To pay an amanuensis to make a clean copy for the press was the responsible way to ensure an error-free publication. In Francesco Vettori's portrayal, to rely on that help but no other help was to be the best kind of humanist author.

\section{CONCLUSION}

Many factors affected the decisions involved in when and what to delegate and to whom, and the specifics are rarely recorded in writing that survives. Many questions will therefore perforce remain unanswered. Nonetheless we can argue that the availability of mechanized copying in the form of printing was one factor that contributed to the rise in status of handwriting and the growing attention to autography in the 15 th to 17 th centuries. Authors and scholars continued to rely on helpers for many tasks, from those which were considered to require judgment, such as note-taking, to those considered mechanical such as alphabetizing. Copying, especially to produce a clean manuscript for the printer, and taking dictation were the activities of amanuenses most likely to be acknowledged in print or iconography.

\footnotetext{
${ }^{67}$ Raphaële Mouren, "Sébastien Gryphe et Piero Vettori: de la querelle des Lettres familières aux agronomes latins," in Mouren (ed.), Quid Novi?, pp. 287-339, at p. 321. ${ }^{68}$ See the observation, based on modern examples, that "the myth of the author's prominence is strongly cherished by the people who most know about the author's failings." Jack Stillinger, Multiple authorship and the myth of the solitary genius (Oxford: Oxford University Press, 1991), p. 155.
} 